\title{
Rancang Bangun Geographic Information System (GIS) Sebagai Pengembangan Sistem Monitoring Area Perkebunan Berbasis IoT
}

\author{
Nadia Thereza1,*, Iwan Pahendra Anto Saputra', Zaenal Husin ${ }^{2}$ \\ ${ }^{1}$ Fakultas Teknik, Teknik Elektro, Universitas Sriwijaya, Palembang, Indonesia \\ Email: 1, ${ }^{*}$ nadia.thereza@gmail.com, ${ }^{1}$ iwanpahendra@gmail.com, ${ }^{2}$ zaenalhusin@gmail.com \\ *) Email Penulis Utama
}

\begin{abstract}
Abstrak- Operasional sektor perkebunan di Indonesia sebagian besar masih mengandalkan sistem konvensional yang menggunakan tenaga manusia untuk melakukan kontrol ke lapangan. Dengan kondisi tersebut, masih sulit jika ingin melakukan peningkatan kinerja operasional menjadi lebih efisien, efektif, dan produktif. Ditambah lagi, kondisi pandemi yang tengah dihadapi saat ini secara tidak langsung sangat berdampak dan berpotensi menurunkan angka produktivitas. Sistem operasional ataupun pengelolaan lahan perkebunan harus mengalami perubahan. Pemanfaatan teknologi dan inovasi sangat dibutuhkan untuk membantu mempertahankan ataupun meningkatkan kualitas dan kuantitas hasil produksi. Oleh sebab itu, dibutuhkan suatu rancangan sistem informasi berbasis website, yang bekerja menyampaikan informasi kondisi geografis suatu area secara real-time sebagai solusi dari permasalahan pemantauan kondisi geografis. Sistem informasi tersebut bekerja menggunakan informasi berupa data spasial (bereferensi geografis) yang dikenal dengan Sistem Informasi Geografis atau Geographic Information System (GIS). Tujuan penelitian ini adalah untuk membangun GIS berbasis web guna memberikan informasi dan menggambarkan kondisi (normal, rawan, kritis) pada suatu area/lahan secara real-time. Metode penelitian ini terdiri dari lima tahapan, yaitu persiapan penelitian (studi literatur), pengkajian objek (observasi, analisis kebutuhan sistem), perancangan dan pembangunan GIS dan integrasi dengan IoT, analisis dan pengujian penerapan GIS, serta penarikan kesimpulan. Sistem informasi geografis yang dibuat adalah dengan menampilkan peta (maps) area yang dipantau. Perangkat lunak yang digunakan untuk menampilkan maps adalah Google Maps Platform yang mana pada platform tersebut terdapat interface yang disebut API (Application Programming Interface). Google Maps API digunakan untuk menghubungkan sistem informasi geografis yang berbasis website dengan google maps. GIS memberikan informasi dan menggambarkan kondisi geografis suatu area secara real-time, kondisi area yang normal ditandai dengan warna hijau, kondisi antara (rawan kritis) ditandai dengan warna kuning serta kondisi area yang kritis ditandai dengan warna merah. Dengan adanya sistem informasi geografis, maka membantu para pekerja lapangan dalam memantau kondisi geografis suatu area secara real-time tanpa harus berada langsung di lokasi. Berdasarkan hasil penilaian pengguna, sebagian besar menyatakan "sangat setuju" bahwa GIS ini bermanfaat, bersifat user-friendly, mudah diakses kapanpun dan di manapun, serta memiliki kecepatan akses yang baik. Selain itu, sebagian besar juga menyatakan "setuju" bahwa GIS mampu menampilkan informasi yang akurat dan dapat membantu pekerjaan.
\end{abstract}

Kata Kunci: GIS, Google Maps API, website, sistem monitoring, real-time, IoT

\begin{abstract}
Most of the plantation sector operations in Indonesia still rely on conventional systems that use human labor to control the field. Under these conditions, it is still difficult to improve operational performance to be more efficient, effective and productive. In addition, the current pandemic condition that is currently being faced has an indirect impact and has the potential to reduce the productivity. The operational system or management of plantation have to be improved. The use of technology and innovation is needed to help maintain or improve the quality and quantity of production. Therefore it is necessary to design a website-based information system that functions to convey information about the geographical conditions of an area in real-time as a solution to the problem of monitoring geographic conditions. This information system works using information in the form of spatial data (geographically referenced) known as a Geographic Information System (GIS). The purpose of this research is to build a web-based GIS to provide information and describe conditions (normal, vulnerable, critical) in an area / land in real-time. This research method consists of five stages, namely research preparation (literature study), object assessment (observation, system requirements analysis), GIS design and development and integration with IoT, analysis and testing of GIS application, and drawing conclusions. The geographic information system created is to display a map of the area which is being monitored. The software used to display maps is the Google Maps Platform, which has an interface called an API (Application Programming Interface) on this platform. The Google Maps API is used to connect a website-based geographic information system with google maps. GIS provides information and describes the geographical conditions of an area in real-time, normal area conditions are marked in green, intermediate conditions (critical prone) are marked in yellow and critical area conditions are marked in red. With the geographical information system, it helps field workers to monitor the geographical conditions of an area in real-time without having to be directly on the spot. Based on the results of user assessments, most of them "strongly agree" that this GIS is useful, user-friendly, easy to access anytime and anywhere, and has good access speed. Apart from that, most of them also agreed that GIS was able to present accurate information and could help the job.
\end{abstract}

Keywords: GIS, Google Maps API, website, real-time, IoT

\section{PENDAHULUAN}

Sektor perkebunan di Indonesia, baik sistem pemantauan, pemeliharaan, maupun operasionalnya sebagian masih dijalankan dengan sistem konvensional, yaitu menggunakan tenaga manusia secara manual. Dengan kondisi 
tersebut, masih sulit jika ingin melakukan peningkatan kinerja operasional menjadi lebih efisien, efektif, dan produktif. Ditambah lagi, kondisi pandemi yang tengah dihadapi saat ini secara tidak langsung sangat berdampak dan berpotensi menurunkan angka produktivitas. Sistem operasional ataupun pengelolaan lahan perkebunan harus mengalami perubahan. Pemanfaatan teknologi dan inovasi sangat dibutuhkan untuk membantu mempertahankan ataupun meningkatkan kualitas dan kuantitas hasil produksi. Sistem monitoring berbasis IoT dapat dikatakan sebagai salah satu pemanfaatan teknologi yang menjadi solusi untuk memudahkan pekerjaan para pekerja operasional ataupun manajemen. Pada penelitian ini, penulis melakukan pengembangan sistem monitoring menjadi sistem yang tampilannya dapat memudahkan pengguna dalam memantau kondisi geografis suatu area. Sistem monitoring dikembangkan menjadi sistem informasi berbasis website yang bekerja menggunakan informasi berupa data spasial (bereferensi geografis/keruangan) yang dikenal dengan Sistem Informasi Geografis atau Geographic Information System (GIS). GIS digunakan untuk menjelaskan kejadian/kondisi lahan perkebunan secara real-time, merencanakan strategi, dan memprediksi kondisi yang kemungkinan akan terjadi. GIS bekerja mengambil, mengintegrasikan, menganalisis, dan menampilkan data yang secara spasial mereferensikan kepada kondisi permukaan bumi [1].

Rumusan masalah pada penelitian ini adalah bagaimana merancang dan membangun Geographic Information System (GIS) berbasis website untuk dapat memberikan informasi ataupun menggambarkan kondisi geografis (normal, rawan kritis, kritis) suatu area secara real-time.

Nilfred dan Fransiskus pada tahun 2018 melakukan penelitian tentang Geographic Information System (GIS) berbasis website untuk area perkebunan karet di Kabupaten Merauke. GIS tersebut digunakan untuk membantu publikasi dan promosi potensi produksi. Selain itu, GIS juga dimanfaatkan untuk mengembangkan perkebunan karet dengan menerapkan sistem yang terintegrasi dengan Google Map Platform. Sistem berbasis website ini dapat menyajikan informasi berupa lokasi, luas area perkebunan, produksi dan lokasi pengembangan lahan perkebunan karet yang mudah diakses [2].

Faisal, Fatwa, dan Aryo pada tahun 2018 melakukan analisis dosis kebutuhan pupuk tanaman dan sekaligus memantau hasil panen menggunakan sistem informasi pengelolaan perkebunan kelapa sawit berbasis web GIS guna memastikan proses pemupukkan efisien. Selain itu, analisis daerah juga dilakukan dengan menggunakan perangkat lunak GIS berbasis Web GIS yang memiliki kemudahan dari sisi penggunaan dengan pendekatan precision farming agar dapat berjalan dalam jangka Panjang [3].

Pada tahun 2019 Musli Yanto juga melakukan penelitian tentang sistem informasi geografis untuk lokasi perkebunan di sepanjang garis Pantai Pesisir Selatan berbasis android. Perancangan GIS penyebaran lokasi perkebunan di sepanjang garis Pantai Pesisir Selatan berbasis android dapat menentukan lokasi perkebunan penyebaran objek lahan pertanian yang bertujuan untuk membantu Dinas Pertanian Kabupaten Pesisir Selatan dalam mengelola keberadaan persebaran lahan perkebunan. GIS penyebaran lokasi perkebunan ini dibangun dapat memberikan informasi berupa keberadaan geografis serta bentuk hasil perkebunan yang ada di sepanjang garis Pantai Pesisir Selatan [4].

Geographic Information System (GIS) atau adalah sebuah sistem yang dirancang untuk membaca, menyimpan, memanipulasi, menganalisa, mengatur dan menampilkan seluruh jenis data geografis. Akronim GIS terkadang dipakai sebagai istilah untuk geographical information science atau geospatial information studies yang merupakan ilmu studi atau pekerjaan yang berhubungan dengan Geographic Information System. Dalam artian sederhana sistem informasi geografis dapat kita simpulkan sebagai gabungan kartografi, analisis statistik dan teknologi sistem basis data (database) [5].

Sistem Internet of Things atau biasa disingkat IoT, berdasarkan rekomendasi ITU-T Y.2060, memiliki definisi bahwa IoT merupakan sebuah infrastruktur global untuk menciptakan layanan tingkat tinggi dengan menghubungkan benda fisik dan benda virtual dengan berdasar pada teknologi komunikasi dan informasi yang telah ada dan dikembangkan. Sedangkan untuk definisi "Things" itu sendiri dalam frase IoT dapat diartikan sebagai benda fisik atau sesuatu hal dari bidang informasi yang mampu didefinisikan dan dihubungkan dengan jaringan komunikasi [6]. Karakteristik IoT diantaranya adalah komunikasi antar perangkat menggunakan jaringan IP yang bekerjasama dengan berbagai macam protokol-protokol komunikasi, pengiriman data dilakukan melalui middle layer host pada jaringan cloud, perangkat-perangkat membutuhkan koneksi internet yang aktif, serta sistem integrasi yang tanpa batas sehingga membutuhkan solusi yang dapat mengelola semua komunikasi [7].

Fitur-fitur terpenting IoT meliputi artificial intelligence (AI), connectivity, sensor, active engagement (actuator), dan penggunaan perangkat kecil. Artificial Intelligence yaitu IoT pada dasarnya membuat segala sesuatu menjadi "smart", yang berarti meningkatkan setiap aspek kehidupan dengan kekuatan pengumpulan data, algoritma kecerdasan buatan, dan jaringan. Connectivity yaitu teknologi jaringan untuk jaringan IoT berupa skala yang jauh lebih kecil dan lebih murah namun tetap praktis. Sensor yaitu bertindak sebagai instrumen yang menentukan dan mengubah IoT dari jaringan perangkat pasif menjadi sistem aktif yang mampu masuk dalam integrasi dunia nyata. Keterlibatan Aktif (actuator) yaitu IoT memperkenalkan paradigma baru untuk konten, produk aktif, atau keterlibatan layanan. Perangkat kecil yaitu perangkat kecil yang murah dan handal untuk menciptakan suatu sistem yang presisi, skalabilitas, dan fleksibilitas [8]. Selain itu, bagian terpenting dari IoT adalah sumber energi (energy source) dan penyimpanan data (data storage) [9]. 
Wireless Sensor Network (WSN) dapat didefinisikan sebagai self-configured dan infrastructure-less dari jaringan wireless untuk memonitor kondisi lingkungan, seperti suhu, suara, getaran, tekanan, cuaca, cahaya, gerakan, kemudian secara kooperatif mengirimkan data-data tersebut melalui jaringan ke lokasi sentral, dengan tujuan nantinya data-data/informasi dapat diobservasi dan dianalisis [10] [11]

Google Maps Application Programming Interface (Google Maps API) diciptakan untuk dapat dipergunakan oleh para developer untuk menghubungkan Google Map dengan sebuah website. Dengan menggunakan interface tersebut, peta atau maps dapat ditampilkan pada website eksternal. Terdapat empat buah model peta yang terdapat pada Google Maps Platform, yaitu roadmap, satellite, terrain, dan hybrid [12].

API terdiri dari antarmuka untuk pemrograman aplikasi, rumusan-rumusan fungsi, kelas struktur dan hal lain-lainnya yang berhubungan dengan pembangunan sebuah software. Antarmuka ini memudahkan developer atau programmer untuk mendalami suatu software yang kemudian nantinya dapat dilakukan pengembangan dan pengintegrasian dengan software yang lain. Antarmuka ini merupakan penghubung suatu aplikasi dengan aplikasi lainnya dengan memungkinkan developer atau programmer menggunakan sistem-sistem fungsi (function system) yang tersedia. Proses ini dilakukan melalui sebuah sistem operasi [13].

Mambang pada penelitiannya mencari solusi untuk permasalahan sebaran komoditi pertanian dan perkebunan di provinsi Kalimantan Selatan. Selain itu, data statistik hasil pertanian dan perkebunan perlu dimanajemen dengan baik dan benar. Sistem informasi geografis menjadi solusi dalam hal pemetaan lahan dan hasil pertanian dan perkebunan di Kalimantan tersebut. Sistem digunakan untuk mengolah data dan menganalisis tingkat hasil pertanian dan perkebunan [14].

Koko, Indra, dan Juju pada tahun 2015 membangun sebuah sistem informasi geografis berbasis website untuk menentukan lokasi pertambangan batu bara di Provinsi Bengkulu. Karena lahan pertambangan di Bengkulu yang menonjol, maka dibuatkan sebuah sistem informasi yang dapat digunakan untuk menganalisis area lahan pertambangan, guna mengetahui potensi-potensi yang terdapat pada lahan tersebut [15].

Kholil pada tahun 2017 membangun sistem informasi geografis dalam rupa aplikasi berbasis android untuk melaporkan dan melacak tindak kejahatan. Aplikasi yang dinamakan lapor Polri tersebut dapat melakukan pelaporan tindakan secara real-time. Aplikasi ini memanfaatkan geofence dan teknologi Geographic Information System [16].

\section{METODE PENELITIAN}

Diagram alir dari metode penelitian ditunjukkan pada Gambar 1 di bawah ini.

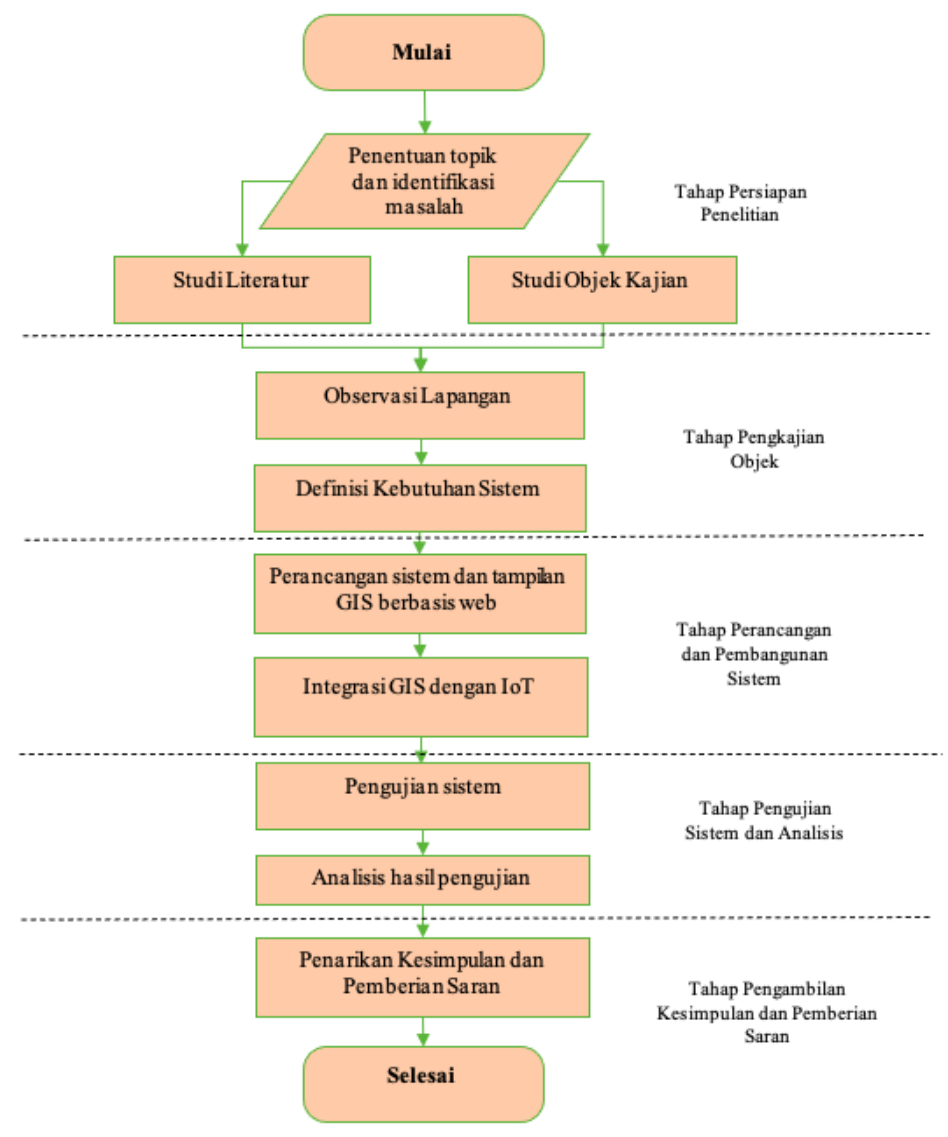

Gambar 1. Skema metodologi penelitian 


\subsection{Tahap Persiapan Penelitian}

Tahap awal pada penelitian ini meliputi penentuan topik dan identifikasi masalah. Penentuan topik dan identifikasi masalah dilakukan dengan mencari isu-isu terbaru terkait dengan bidang teknologi informasi dan komunikasi (ICT), yang nantinya keluaran dari penelitian ini dapat memberikan kontribusi besar dalam bidang ICT. Dilanjutkan dengan mempelajari literatur-literatur dan objek kajian yang berkaitan dengan topik penelitian. Studi objek kajian dilakukan dengan membaca buku, jurnal, ataupun tutorial.

\subsection{Tahap Pengkajian Objek}

Observasi dilakukan untuk mendapatkan informasi-informasi yang dibutuhkan yang berkaitan dengan kebutuhan rancang bangun GIS pada lahan perkebunan. Tahap observasi difokuskan untuk mencatat hal-hal, memperoleh data-data yang dibutuhkan, mengamati proses-proses, dan melakukan wawancara kepada para stakeholder. Pada tahap ini, hasil dari observasi ke lapangan akan digunakan untuk proses identifikasi selanjutnya. Setelah data dan informasi didapat, maka akan dilakukan analisis kebutuhan untuk menentukan hal-hal apa saja yang dibutuhkan untuk membangun GIS, dilanjutkan dengan mengidentifikasi model perancangan GIS untuk diterapkan pada suatu area (lahan perkebunan).

\subsection{Tahap Perancangan dan Pembangunan Sistem}

Pada tahapan ini, hasil dari pengkajian objek dianalisis kemudian dilanjutkan dengan merancang arsitektur sistem yang dihasilkan berdasarkan referensi. Selanjutnya, melakukan perancangan desain interface, data flow diagram, entity relationship diagram, dan physical data model. Dilanjutkan melakukan pengolahan data untuk pembuatan konsep real-world. Konsep real world mengubah realitas suatu lahan menggunakan model menjadi sebuah sistem informasi geografis yang dapat disimpan, dimanipulasi, diproses dan dipresentasikan. Pada awalnya, lahan sesungguhnya akan diubah menjadi model, lalu model-model objek tersebut diubah menjadi sebuah tipe data. Tipe-tipe data tersebut akan disimpan di dalam database server dan hasil akhirnya berupa tampilan maps dan report (chart) pada desktop yang menjadi sebuah sistem informasi geografis. Gambar 2 di bawah ini menunjukkan konsep real world.
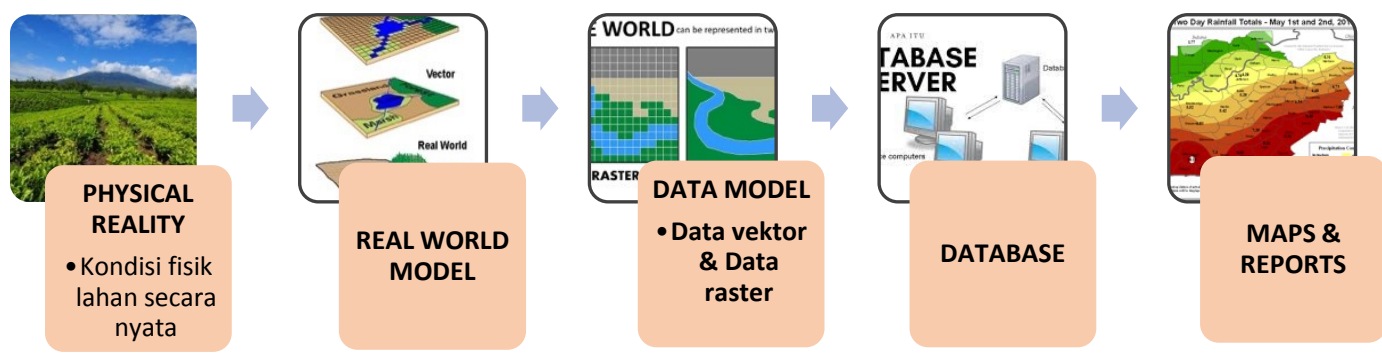

Gambar 2. Konsep real-world [5]

Perangkat lunak yang digunakan untuk membangun sistem informasi geografis pada penelitian ini di antaranya: platform Angular, dan Platform Google Maps API. Selain itu, digunakan bahasa pemrograman Python dan Postgre SQL untuk sistem database.

\subsection{Tahap Pengujian Sistem dan Analisis}

Pada tahap ini dilakukan pengujian kinerja sistem tersebut apakah sudah bekerja dengan baik dan efisien untuk nantinya dapat dikembangkan dan diterapkan pada lahan perkebunan. Black box testing dipilih untuk digunakan sebagai alat pengujian sistem. Blak box testing menguji fungsionalitas sistem yang telah dibuat tanpa melihat struktur atau cara kerja internal. Tiap-tiap fungsionalitas yang ada pada GIS diberikan skenario, kemudian diberikan test case. Dalam tahapan ini juga dilakukan user acceptance test dari sisi pengguna.

\subsection{Tahap Penarikan Kesimpulan dan Pemberian Saran}

Tahap akhir dari penelitian ini adalah penarikan kesimpulan mengenai sistem informasi geografis berbasis web GIS yang telah dirancang bangun. Poin-poin kesimpulan dihasilkan untuk menjawab masalah-masalah yang telah dirumuskan pada tahap sebelumnya. Kesimpulan akan dibuat dengan singkat, padat, dan jelas sesuai dengan tujuan penelitian yang telah dibuat pada bab sebelumnya, sehingga dapat memberikan pemahaman yang tepat bagi para pembaca laporan penelitian ini. Setelah dilakukannya penarikan kesimpulan, maka akan diberikan saransaran untuk penelitian selanjutnya.

\subsection{Alat dan Pengujian}

Berikut merupakan Tabel 1 yang menunjukkan daftar perangkat yang digunakan pada penelitian ini. 
Tabel 1. Daftar perangkat

\begin{tabular}{|c|c|c|}
\hline No & Spesifikasi Perangkat & Deskripsi \\
\hline 1 & PostgreSQL & Untuk manajemen basis data (database) \\
\hline 2 & Python 3.8 & Bahasa pemrograman \\
\hline 3 & Angular Javascript & Framework untuk membuat website \\
\hline 4 & Google Maps Platform & $\begin{array}{l}\text { Untuk mengintegrasikan Google Maps } \\
\text { ke website }\end{array}$ \\
\hline 5 & D1 mini protoboard shield & $\begin{array}{l}\text { Protoboard untuk D1 mini } \\
\text { Modul long-range wireless }\end{array}$ \\
\hline 6 & LoRa Ra-02 SX1278 & $\begin{array}{l}\text { Dengan spektrum } 10 \mathrm{~km} \text { dengan range } \\
\text { frekuensi } 420-450 \mathrm{MHz}\end{array}$ \\
\hline 7 & BME280 Sensor & $\begin{array}{l}\text { Sensor pengukur tekanan, suhu, altitude, } \\
\text { dan kelembaban udara }\end{array}$ \\
\hline 8 & $\begin{array}{l}\text { D1 Mini Lithium (LiPo) } \\
\text { Battery Supply Charging } \\
\text { Shield }\end{array}$ & $\begin{array}{l}\text { Shield untuk power supply dan battery } \\
\text { charging }\end{array}$ \\
\hline 9 & $\begin{array}{l}\text { D1 mini NodeMCU Lua } \\
\text { wifi board }\end{array}$ & $\begin{array}{l}\text { Mini wifi board based on ESP-8266EX } \\
\text { untuk terhubung ke sistem komunikasi }\end{array}$ \\
\hline 10 & $\begin{array}{l}\text { Connector jst XH 2,52 pin } \\
\text { (male \& female) }\end{array}$ & $\begin{array}{l}\text { Digunakan untuk rechargeable battery } \\
\text { packs. }\end{array}$ \\
\hline 11 & $\begin{array}{l}\text { Dual Base Shield D1 Mini } \\
\text { WiFi ESP8266 IoT }\end{array}$ & $\begin{array}{l}\text { Untuk menghubungkan shield dengan } \\
\text { D1 mini. }\end{array}$ \\
\hline 12 & $\begin{array}{l}\text { Panel Surya \& Battery } \\
\text { Li-on }\end{array}$ & Sumber energi listrik \\
\hline 13 & Spring Antenna & $\begin{array}{l}\text { Penangkap sinyal (transmitter } \& \\
\text { receiver) }\end{array}$ \\
\hline 14 & Personal Computer & Sebagai server untuk sistem \\
\hline 15 & Tiang, pipa \& konektor & $\begin{array}{l}\text { Peralatan pendukung perakitan } \\
\text { perangkat }\end{array}$ \\
\hline
\end{tabular}

\subsection{Sistem Pengujian}

Pengujian dilakukan menggunakan blackbox testing. Menguji fungsionalitas sistem yang telah dibuat tanpa melihat struktur atau cara kerja internal. Tiap-tiap fungsionalitas yang ada pada GIS diberikan skenario, kemudian diberikan contoh kasus (test case). Selanjutnya dilihat apakah hasilnya sesuai dengan yang diharapkan. Kemudian dilakukan pula user acceptance test menggunakan kuesioner. Kuesioner diberikan kepada beberapa pengguna untuk melihat tingkat kepuasan dan kinerja sistem apakah telah memenuhi target.

\section{HASIL DAN PEMBAHASAN}

\subsection{Lokasi Penempatan Node Sensor}

Penelitian ini dilakukan di Laboratorium TTI (Teknik Telekomunikasi dan Informasi) pada Program Studi Teknik Elektro Universitas Sriwijaya. Berdasarkan hasil identifikasi permasalahan, maka dirancang sebuah sistem informasi geografis yang dapat merepresentasikan kondisi geografis area pantauan (suhu, tekanan udara, kelembaban udara, dan curah hujan) secara real-time. Lokasi area yang dipilih untuk dijadikan lokasi penempatan sensor adalah di kawasan Universitas Sriwijaya Kampus Palembang. Lokasi ini dipilih untuk merepresentasikan area perkebunan. Jumlah node sensor yang digunakan adalah sebanyak dua buah node dengan simbol A1 untuk area 1 dan A2 untuk area 2. Gambar 3 di bawah ini merupakan gambar peta (map) yang dijadikan lokasi penempatan dua buah node sensor. 


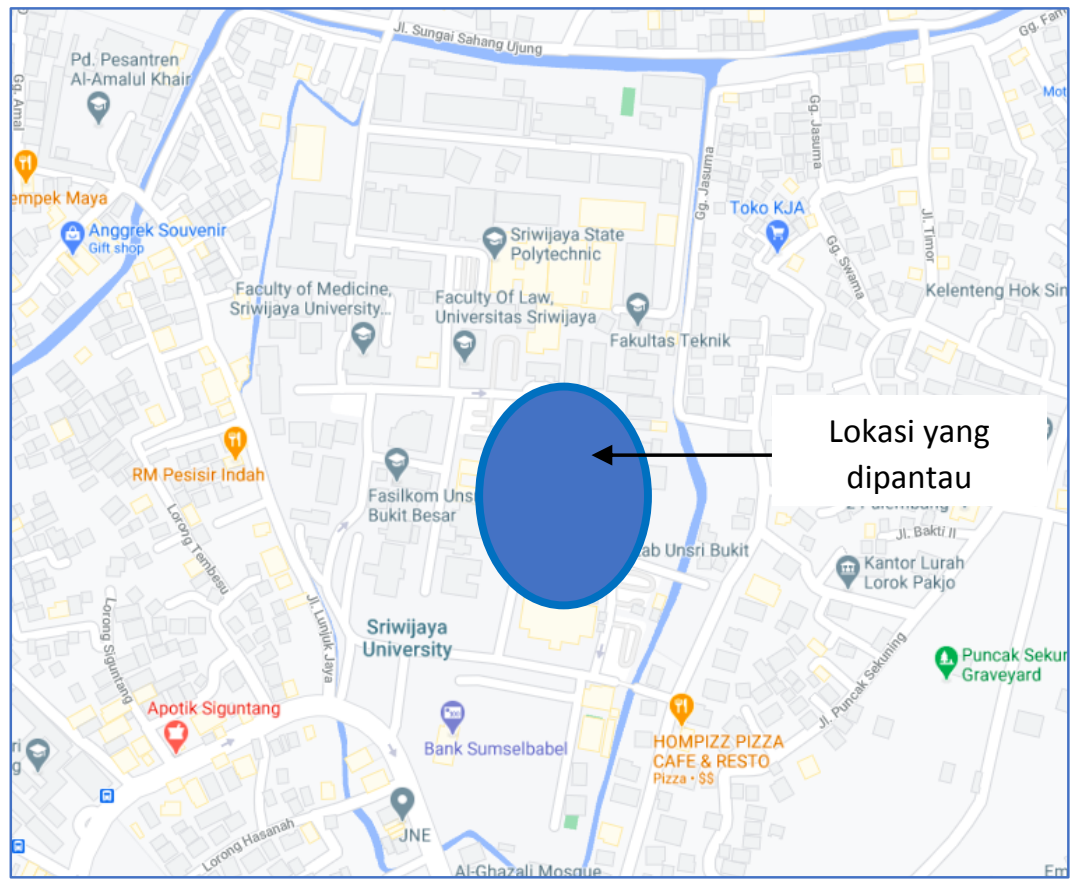

Gambar 3. Lokasi penempatan dua buah node sensor

\subsection{Perangkat Keras}

Perangkat keras yang dirancang bangun pada penelitian ini terdiri dari dua bagian, yaitu sisi pengirim (transmitter) dan sisi penerima (receiver).

\subsubsection{Sisi pengirim (transmitter)}

Serangkaian perangkat yang digunakan sebagai sisi transmitter ditunjukkan pada Gambar 4 di bawah ini.

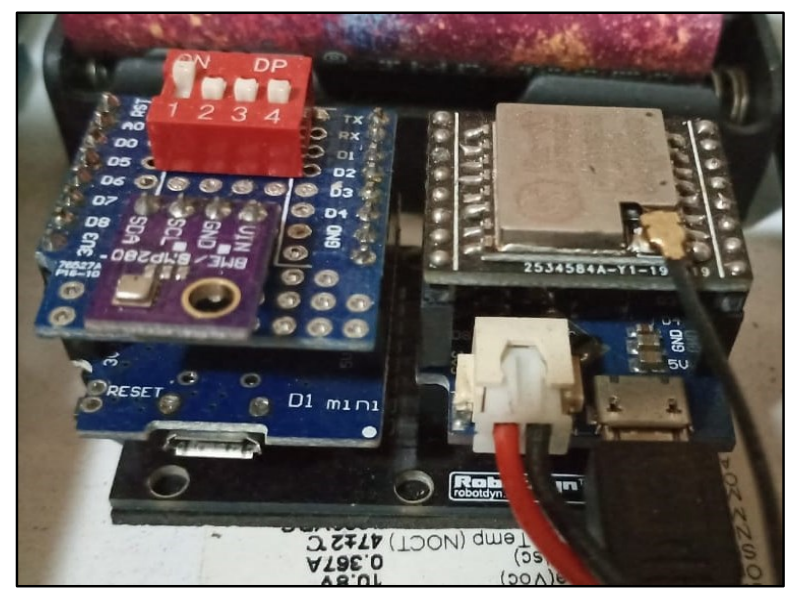

Gambar 4. Perangkat pada sisi transmitter

Gambar 5 (a) dan (b) menunjukkan alat pada sisi transmitter yang digabungkan dengan sebuah panel surya. Panel surya digunakan sebagai sumber energi utama pada alat. Sedangkan untuk sumber energi alternatif menggunakan batere. 


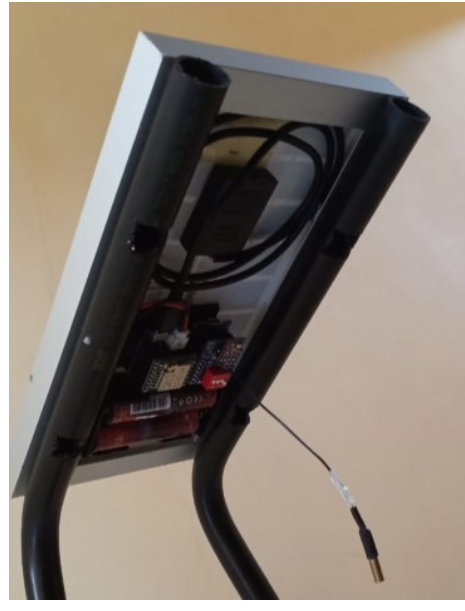

(a)

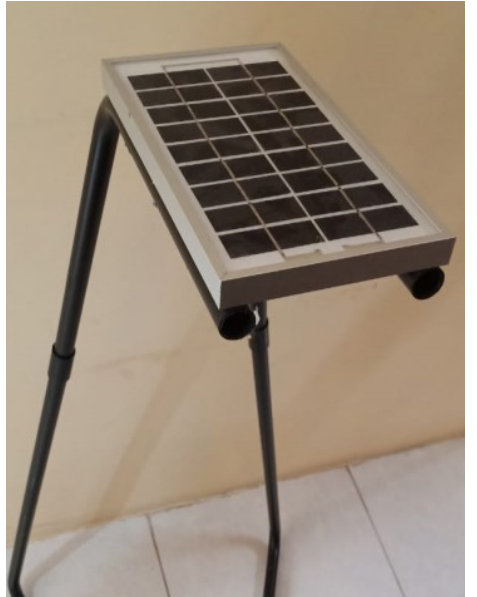

(b)

Gambar 5. (a) Alat pada sisi transmitter tampak dari bawah (b) Alat pada sisi transmitter tampak dari atas

\subsubsection{Sisi penerima (receiver)}

Gambar 6 di bawah ini menunjukkan bagian pada sisi receiver yang dihubungkan ke sebuah PC dengan menggunakan konektor.

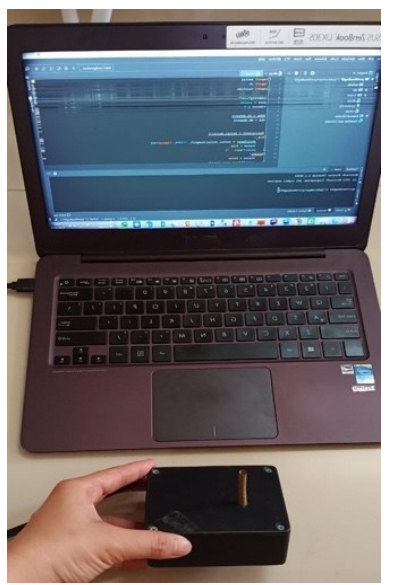

Gambar 6. Perangkat pada sisi receiver yang terhubung ke PC

\subsection{Perangkat Lunak}

\subsubsection{Google Maps Platform}

Pada penelitian ini, sistem informasi geografis yang dibuat adalah dengan menampilkan peta (maps) area yang ingin dipantau. Perangkat lunak yang digunakan untuk menampilkan peta atau maps adalah Google Maps Platform yang mana pada platform tersebut terdapat interface yang disebut API (Application Programming Interface). Google Maps API pada penelitian ini digunakan untuk menghubungkan sistem informasi geografis yang berbasis website dengan google maps API. Bahasa pemrograman yang digunakan adalah javascript API (untuk front-end).

\subsubsection{Simple Polygon}

Untuk merepresentasikan area yang dikhendaki, penulis memilih menggunakan simple polygon. Poligon merepresentasikan area yang dipilih dengan sistem atau jalur yang tertutup atau bersifat loop. Loop tersebut ditentukan oleh titik-titik koordinat. Masing-masing titik koordinat memiliki nilai longitude dan latitude. Simple polygon dapat ditunjukkan dengan garis tepi ataupun daerah isian pada sebuah loop. Penulis menentukan warna pada daerah isian dengan ragam warna merah, kuning, hijau muda, dan hijau tua [17].

\subsection{Hasil Rancangan dan Implementasi Sistem}

Pada Gambar 7 di bawah ini merupakan cuplikan line code yang digunakan untuk dapat terhubung ke database. Bahasa pemrograman yang digunakan adalah Python dan sistem database atau basis data yang digunakan adalah PostgreSQL. 


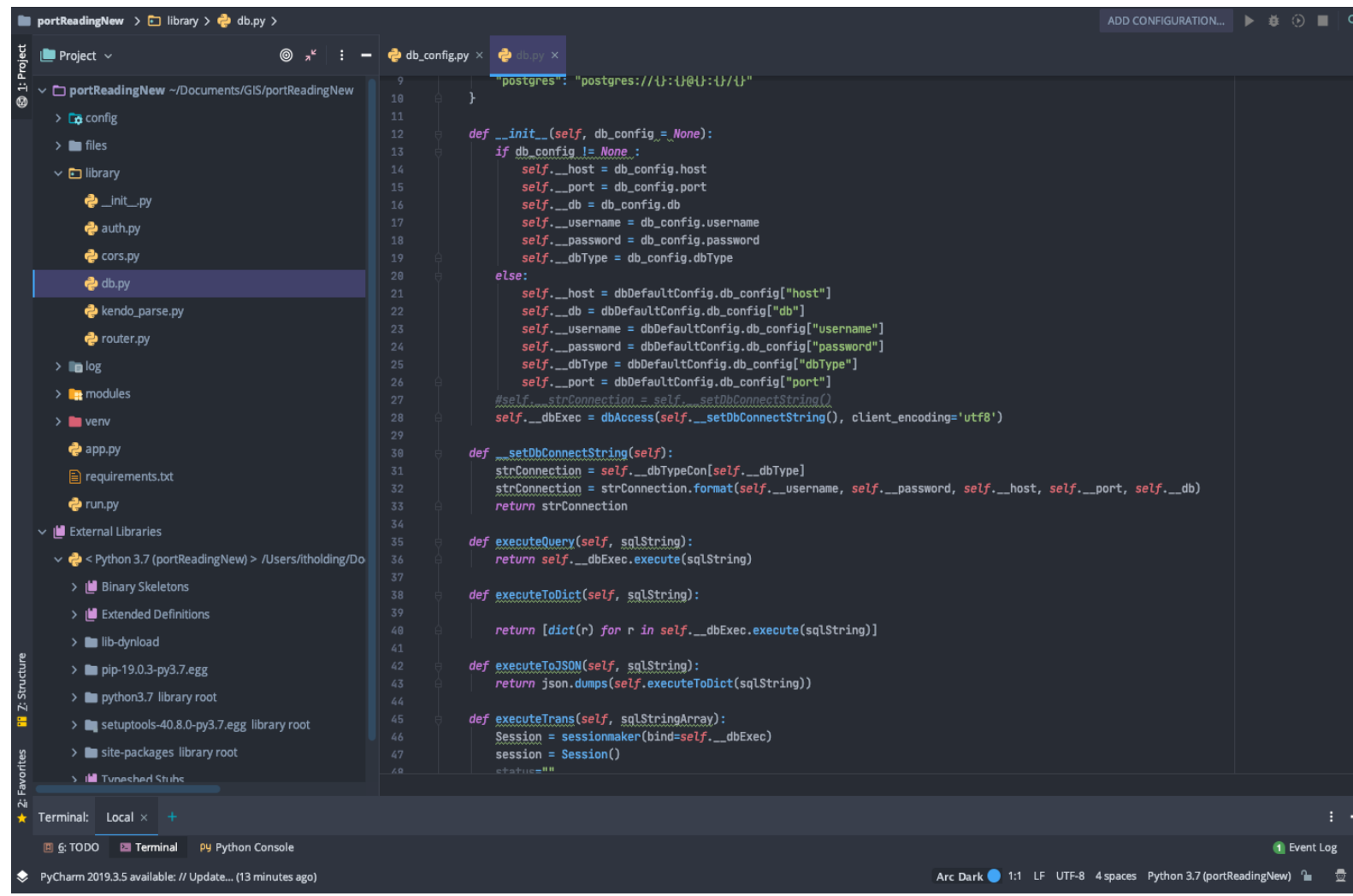

Gambar 7. Tampilan ruang kerja untuk terhubung ke database

Pada Gambar 8 di bawah ini menunjukkan cuplikan ruang kerja dan line code yang digunakan dalam membangun dan men-debug sistem informasi geografis (GIS) berbasis website.

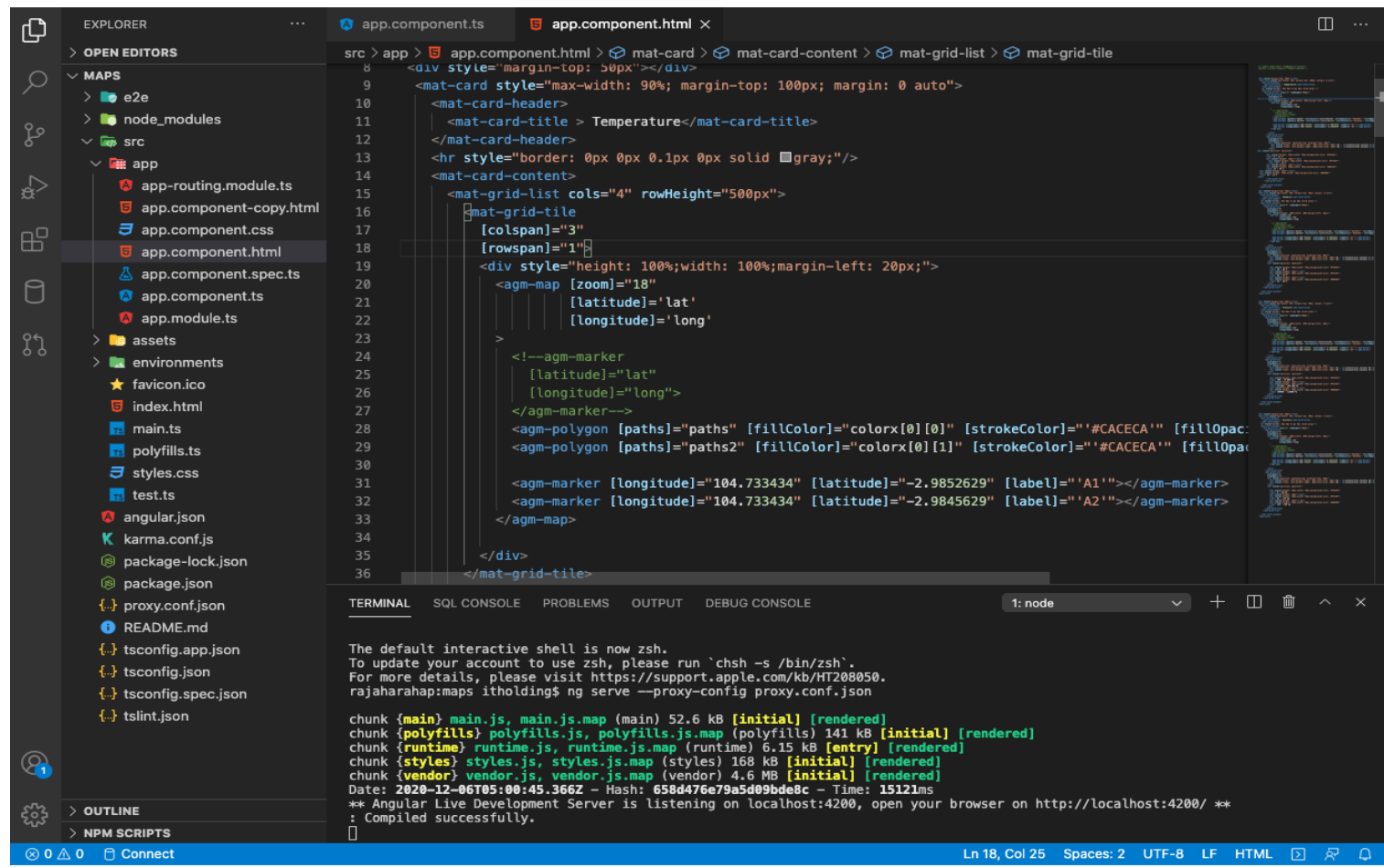

Gambar 8. Cuplikan ruang kerja dan line code yang digunakan dalam membangun dan men-debug sistem informasi geografis (GIS) berbasis website

Tampilan data yang dihasilkan dari dua buah sensor bersifat real-time. User dapat melakukan pemantauan kondisi parameter area secara langsung (menggunakan sistem informasi berbasis website) dan real-time tanpa harus berada langsung di lokasi pemantauan. Pada penelitian ini, satu buah node sensor akan membaca empat buah parameter lingkungan, yaitu suhu (temperature), kelembaban udara (humidity), tekanan udara (pressure) 
dan curah hujan (rainfall). GIS menggambarkan kondisi geografis area yang dipantau, kondisi area yang normal ditandai dengan warna hijau muda dan hijau tua, kondisi antara (rawan kritis) ditandai dengan warna kuning serta kondisi area yang kritis ditandai dengan warna merah.

Pada Gambar 9 di bawah ini menunjukkan tampilan data suhu pada area yang dipantau. Untuk suhu udara dengan rentang $0^{\circ} \mathrm{C}$ sampai $17^{\circ} \mathrm{C}$ dipetakan dengan warna merah, suhu di dalam rentang tersebut dianggap berada pada kondisi kritis. Untuk suhu udara dengan rentang $17^{\circ} \mathrm{C}$ sampai $21^{\circ} \mathrm{C}$ dipetakan dengan warna kuning, suhu yang berada dalam rentang tersebut dianggap rawan kritis. Untuk suhu udara dengan rentang $22^{\circ} \mathrm{C}$ sampai $24^{\circ} \mathrm{C}$ dipetakan dengan warna hijau muda, suhu yang berada dalam rentang tersebut merupakan suhu yang dianggap cukup baik (normal). Untuk suhu udara dengan rentang $24^{\circ} \mathrm{C}$ sampai $32^{\circ} \mathrm{C}$ dipetakan dengan warna hijau tua yang merupakan rentang suhu yang dianggap paling baik (normal). Dilihat dari gambar di bawah ini, area pertama A1 (node sensor 1) menampilkan warna hijau tua dengan suhu $28,48^{\circ} \mathrm{C}$ dan area kedua $\mathrm{A} 2$ (node sensor 2) menampilkan warna hijau muda dengan suhu $23,80^{\circ} \mathrm{C}$.

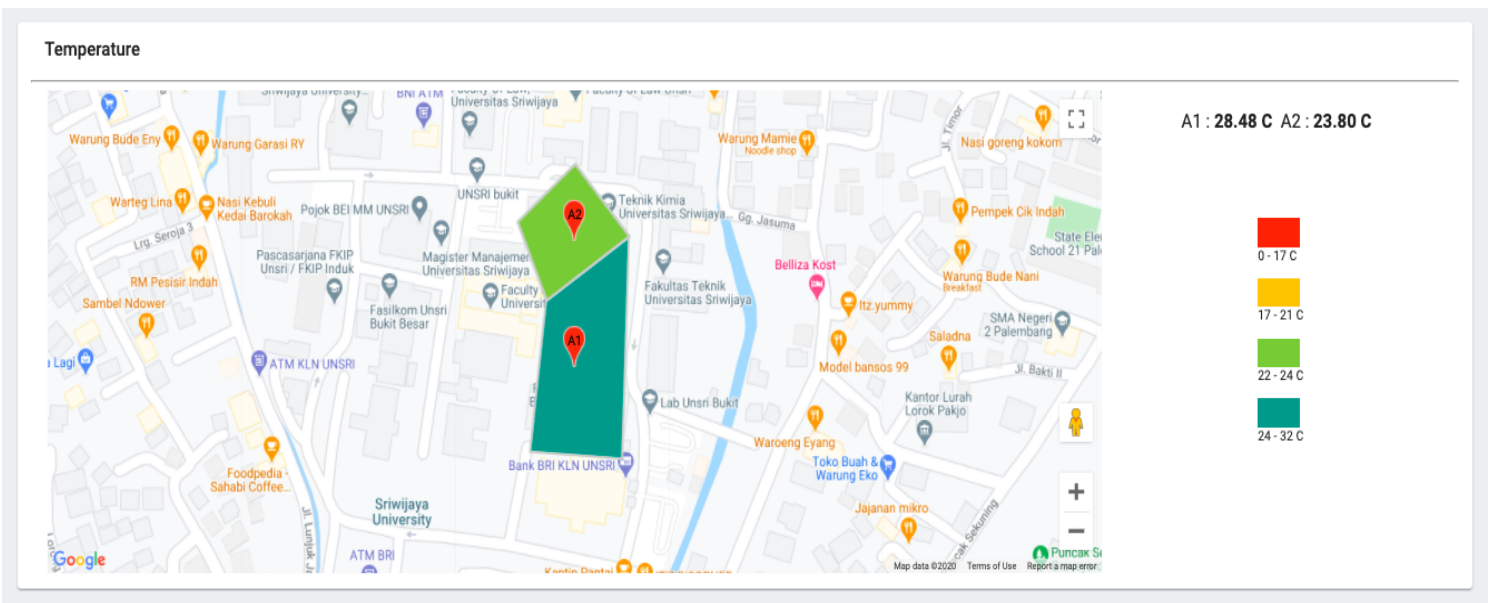

Gambar 9. Tampilan data suhu (temperature) secara real-time

Pada Gambar 10 di bawah ini menunjukkan tampilan data kelembaban udara pada area yang dipantau. Untuk kelembaban udara dalam rentang 10\% - 60\% dipetakan dengan warna merah. Nilai kelembaban udara pada rentang tersebut dianggap berada pada kondisi kritis . Untuk kelembaban udara dalam rentang $61 \%-74 \%$ dipetakan dengan warna kuning, nilai kelembaban udara yang berada pada rentang tersebut dianggap berada pada kondisi rawan kritis. Untuk kelembaban udara dalam rentang 75\% - 80\% dipetakan dengan warna hijau. Nilai kelembaban udara pada rentang tersebut dianggap berada pada kondisi paling baik (normal). Dilihat dari gambar di bawah ini, area pertama A1 (node sensor 1) menampilkan warna kuning dengan nilai kelembaban udara $68,11 \%$ dan area kedua A2 (node sensor 2) menampilkan warna merah dengan nilai kelembaban udara 58,02\%.

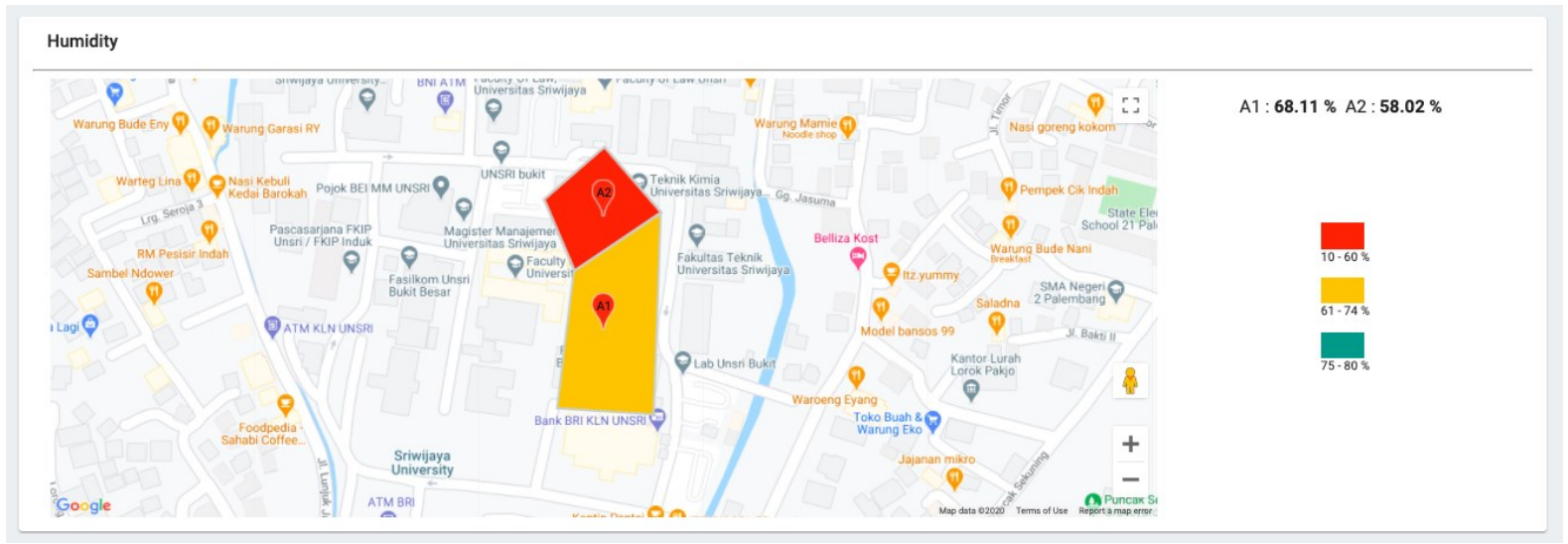

Gambar 10. Tampilan data kelembaban udara (humidity) secara real-time

Pada Gambar 11 di bawah ini menunjukkan tampilan data curah hujan pada area yang dipantau. Satuan curah hujan harian dihitung dengan satuan "mm" yang merupakan satuan penyederhanaan dari satuan liter per meter persegi $\left(l / \mathrm{m}^{2}\right)$. Jadi, jika dikatakan suatu area memiliki curah hujan $1 \mathrm{~mm}$, maka area tersebut tergenangi air sebanyak 1 liter di atas permukaan tanah seluas $1 \mathrm{~m}^{2}$. Untuk curah hujan $0-60 \mathrm{~mm}$ per hari dipetakan dengan warna merah, nilai curah hujan yang berada pada rentang tersebut dapat dikatakan bahwa area tersebut berada pada kondisi kritis. Untuk curah hujan 61 - 119 mm per hari dipetakan dengan warna kuning, nilai curah hujan 
yang berada dalam rentang tersebut dapat menyebabkan area berada pada kondisi rawan kritis. Untuk curah hujan $120-250 \mathrm{~mm}$ per hari dipetakan dengan warna hijau, nilai curah hujan yang berada dalam rentang tersebut dapat menimbulkan kondisi yang paling baik (normal). Dilihat dari gambar di bawah ini, area pertama A1 (node sensor 1) menampilkan warna hijau dengan nilai curah hujan $246,81 \mathrm{~mm}$ dan area kedua A2 (node sensor 2 ) menampilkan warna kuning dengan nilai curah hujan $83,76 \mathrm{~mm}$.

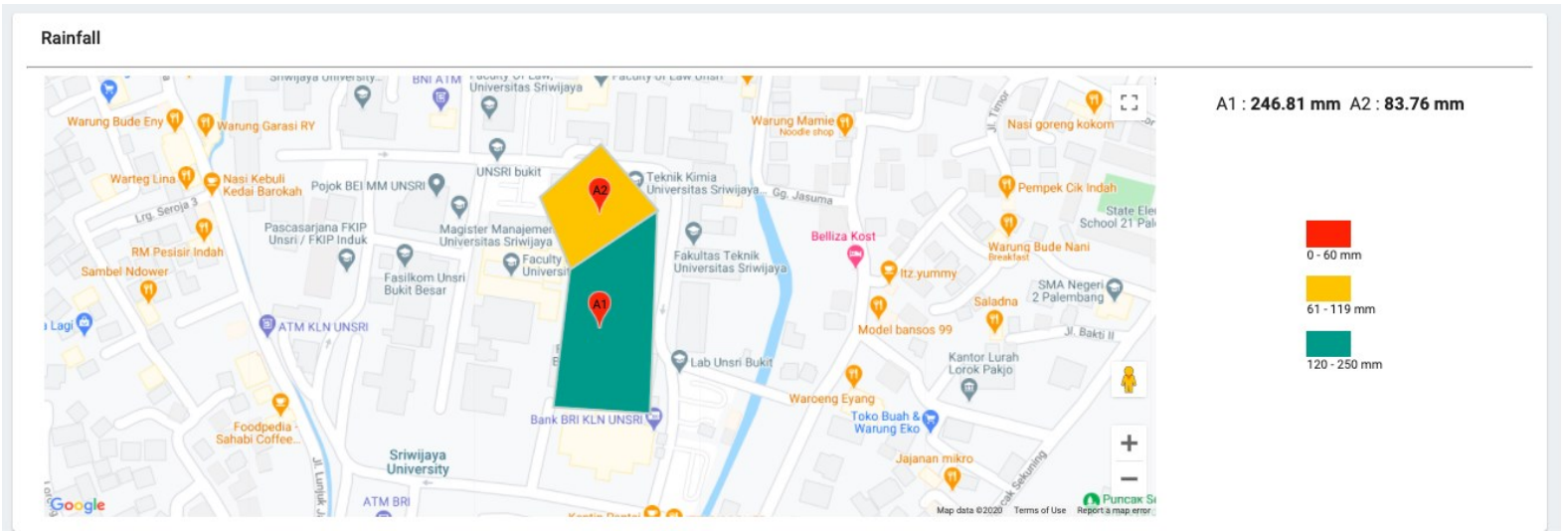

Gambar 11. Tampilan data curah hujan (rainfall) secara real-time

Pada Gambar 12 di bawah ini menunjukkan tampilan data tekanan udara pada area yang dipantau. Untuk tekanan udara 300 - 79.000 $\mathrm{Pa}$ (pascal) dipetakan dengan warna merah. Jika, nilai tekanan udara yang terbaca oleh sensor berada pada rentang tersebut, maka dianggap area tersebut berada pada kondisi kritis. Untuk tekanan udara 80.000 - 100.000 Pa (pascal) dipetakan dengan warna kuning, nilai tekanan udara yang berada rentang tersebut dapat dianggap berada pada kondisi rawan kritis. Untuk tekanan udara 100.000 - 110.000 Pa (pascal) dipetakan dengan warna hijau. Jika, nilai tekanan udara yang terbaca oleh sensor berada pada rentang tersebut, maka dianggap area tersebut berada pada kondisi paling baik (normal). Dilihat dari gambar di bawah ini, area pertama A1 (node sensor 1) menampilkan warna hijau dengan nilai tekanan udara sebesar 108574,58 Pa dan area kedua A2 (node sensor 2) menampilkan warna kuning dengan nilai tekanan udara sebesar 97866,32 Pa.

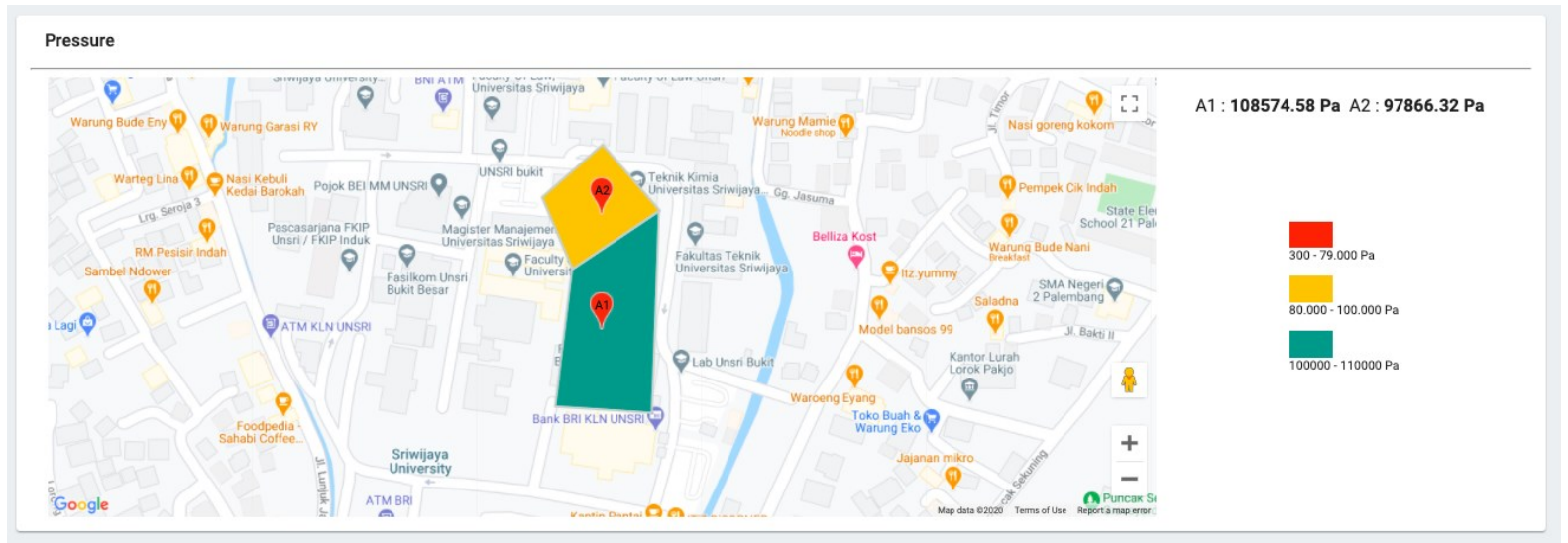

Gambar 12. Tampilan data tekanan udara (pressure) secara real-time

Sistem informasi greografis ini memberikan informasi secara real-time mengenai kondisi geografis (suhu, tekanan udara, kelembaban udara, dan curah hujan) dari suatu area. Ragam warna yang ditunjukkan pada peta akan berubah-ubah sesuai dengan nilai yang terukur oleh sensor (suhu, tekanan udara, kelembaban udara, dan curah hujan).

\subsection{Hasil Pengujian Kuesioner Pengguna}

Pengujian ini dilakukan dengan memberikan kuesioner berisi lima buah pernyataan kepada 10 orang pengguna/responden (orang-orang yang berkepentingan mengenai sistem monitoring/pemantauan). Tujuan pemberian kuesioner adalah untuk melihat respon pengguna tehadap sistem dan mengukur kinerja sistem . Berikut merupakan lima buah pernyataan yang diberikan:

a. GIS ini bermanfaat bagi para pengguna dalam memantau kondisi geografis suatu area secara real-time.

b. GIS ini mudah untuk digunakan atau bersifat user-friendly.

c. Jika GIS ini diterapkan di tempat Anda bekerja, maka akan sangat membantu pekerjaan Anda. 
d. GIS ini mudah untuk diakses kapanpun dan di manapun saat dibutuhkan.

e. GIS ini memiliki kecepatan akses yang baik saat digunakan.

f. GIS ini menghasilkan informasi yang akurat.

Berdasarkan hasil penilaian pengguna menggunakan kuesioner, berikut adalah persentase penilaian pengguna terhadap aspek fungsionalitas sistem.

a. Pernyataan 1: GIS ini bermanfaat bagi para pengguna dalam memantau kondisi geografis suatu area secara real-time. Pada Gambar 13 di bawah ini dapat dilihat bahwa sebagian besar responden menyatakan sangat setuju bahwa GIS ini bermanfaat dalam memantau area secara real-time. Rincian hasil penilaian pengguna terhadap pernyataan 1 adalah sebagai berikut: $80 \%$ responden memilih untuk sangat setuju dan $20 \%$ responden memilih untuk setuju.

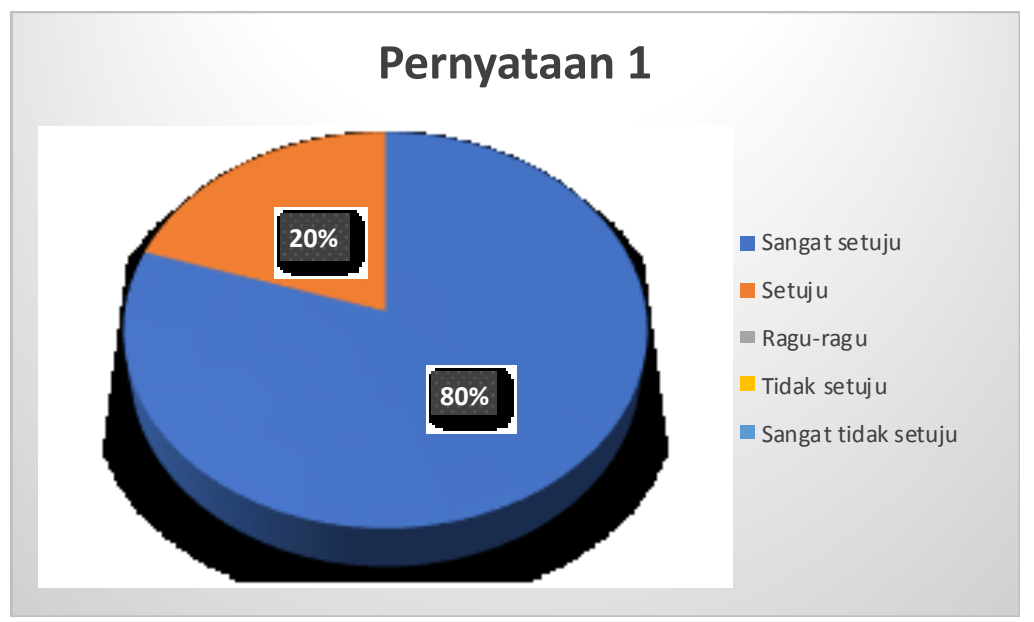

Gambar 13. Grafik persentase respon terhadap pernyataan 1

b. Pernyataan 2: GIS ini mudah untuk digunakan atau bersifat user-friendly. Dilihat dari Gambar 14 di bawah ini, sebagian besar responden menyatakan sangat setuju bahwa GIS ini bersifat user-friendly. Rincian hasil penilaian pengguna terhadap pernyataan 2 adalah sebagai berikut: $60 \%$ responden memilih untuk sangat setuju dan $40 \%$ responden memilih untuk setuju.

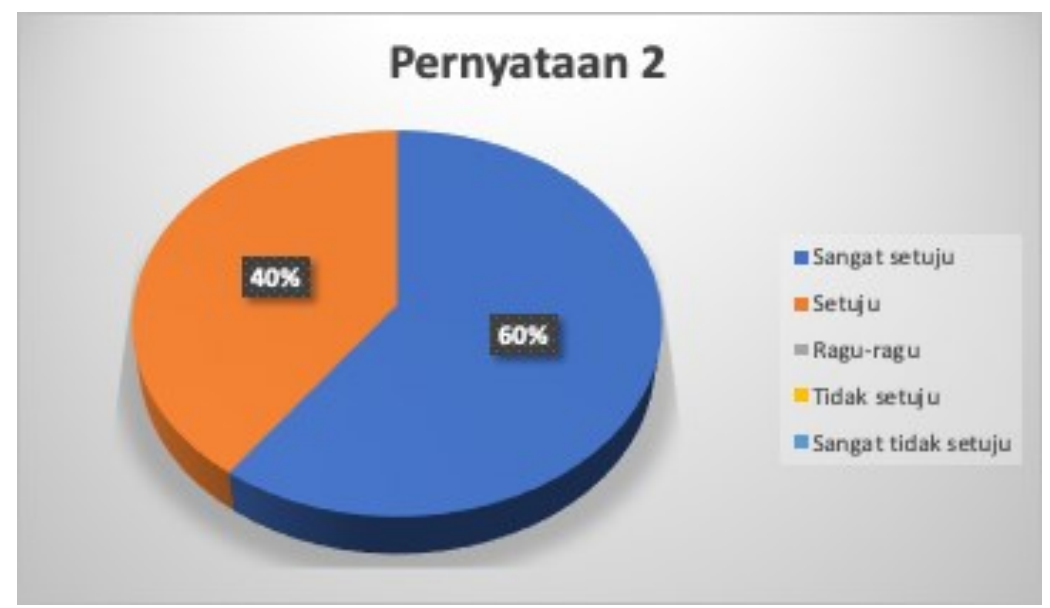

Gambar 14. Grafik persentase respon terhadap pernyataan 2

c. Pernyataan 3: Jika GIS ini diterapkan di tempat Anda bekerja, maka akan sangat membantu pekerjaan Anda. Pada Gambar 15 di bawah ini, dapat dilihat bawah sebagian besar responden menyatakan setuju bahwa GIS dapat membantu pekerjaan mereka. Rincian hasil penilaian pengguna terhadap pernyataan 3 adalah sebagai berikut: $70 \%$ responden sangat setuju, $20 \%$ responden setuju, dan $10 \%$ ragu-ragu. 


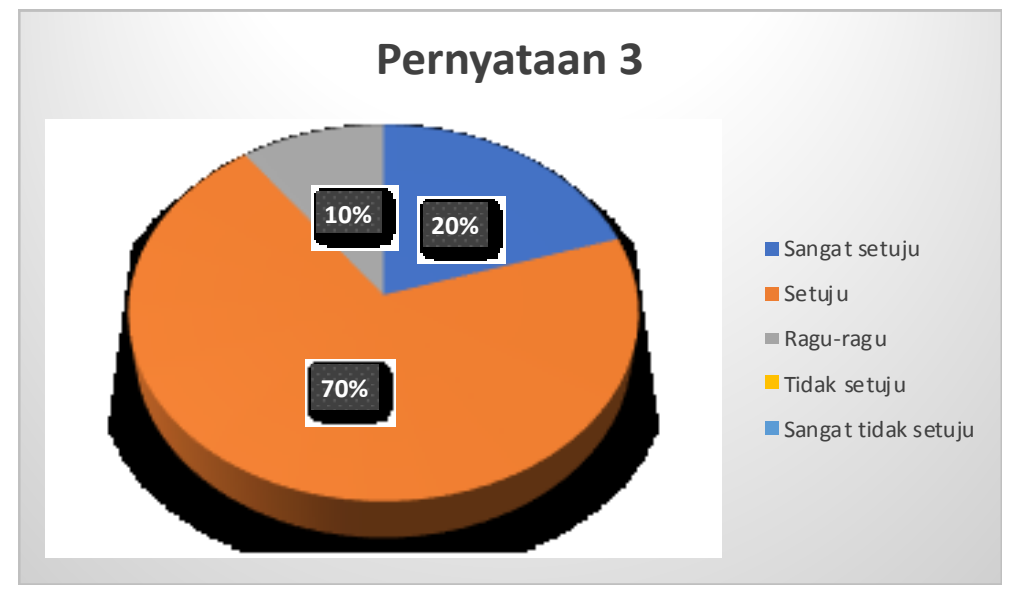

Gambar 15. Grafik persentase respon terhadap pernyataan 3

d. Pernyataan 4: GIS ini mudah untuk diakses kapanpun dan di manapun saat dibutuhkan. Dilihat dari Gambar 16 di bawah ini, sebagian besar responden menyatakan sangat setuju bahwa GIS ini mudah untuk diakses. Rincian hasil penilaian pengguna terhadap pernyataan 4 adalah sebagai berikut: $50 \%$ responden memilih untuk sangat setuju, $40 \%$ responden memilih untuk setuju, dan 10\% responden ragu-ragu.

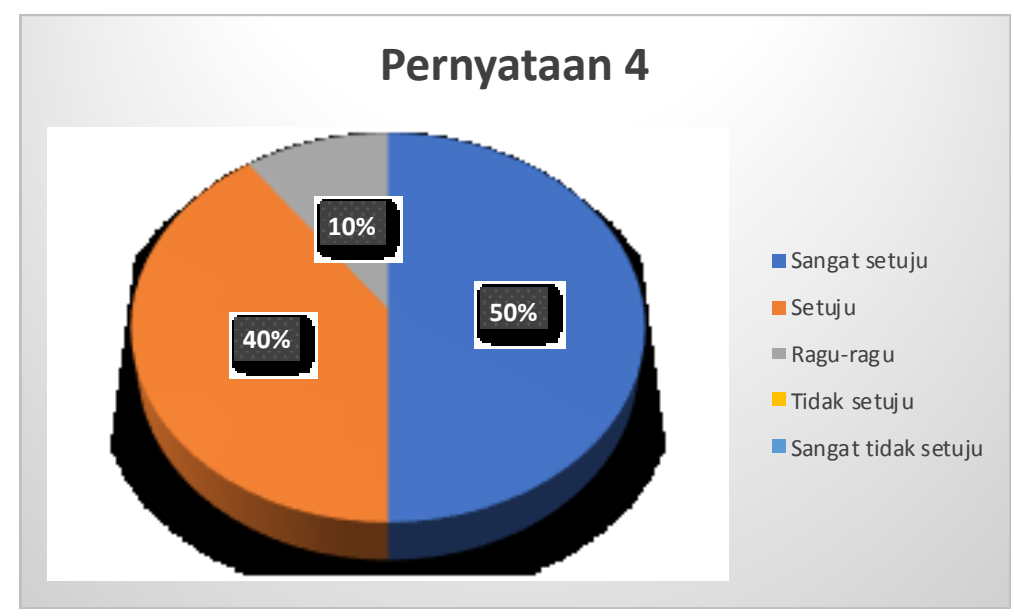

Gambar 16. Grafik persentase respon terhadap pernyataan 4

e. Pernyataan 5: GIS ini memiliki kecepatan akses yang baik saat digunakan. Pada Gambar 17 di bawah ini dapat dilihat bahwa sebagian besar responden menyatakan sangat setuju bahwa GIS ini memiliki akses yang cepat. Rincian hasil penilaian pengguna terhadap pernyataan 5 adalah sebagai berikut: $70 \%$ responden menyatakan sangat setuju dan $30 \%$ responden menyatakan setuju.

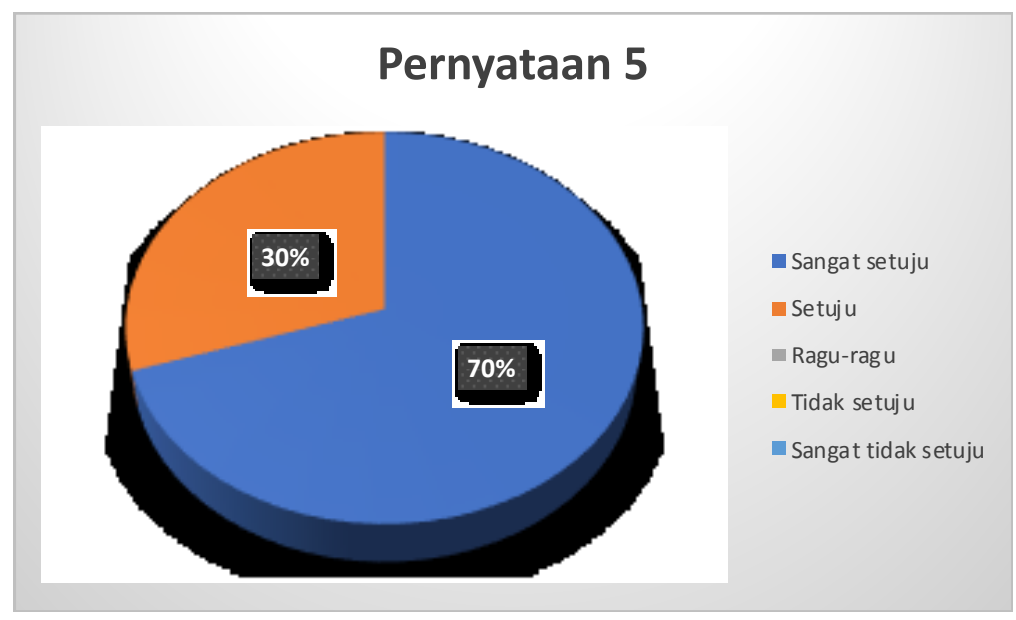

Gambar 17. Grafik persentase respon terhadap pernyataan 5 
f. Pernyataan 6: GIS ini menghasilkan informasi yang akurat. Dilihat dari grafik pada Gambar 18 di bawah ini, sebagian besar responden menyatakan setuju bahwa nilai yang ditampilkan GIS akurat. Rincian hasil penilaian pengguna terhadap pernyataan 6 adalah sebagai berikut:40\% menyatakan sangat setuju dan $60 \%$ responden menyatakan setuju.

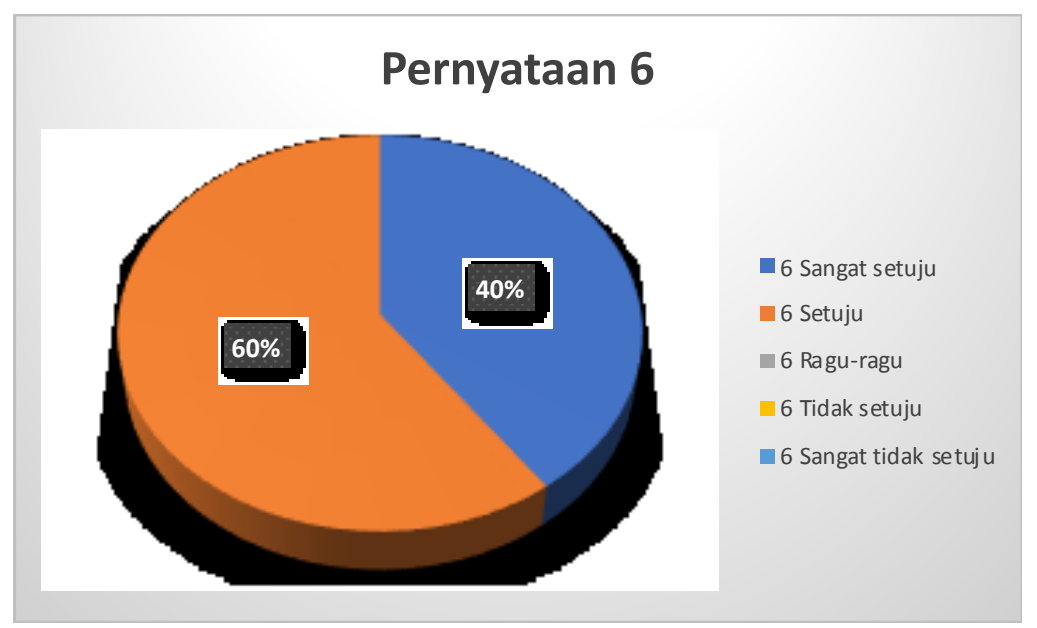

Gambar 18. Grafik persentase respon terhadap pernyataan 6

\subsection{Analisis Hasil Pengujian}

Dari hasil pengujian dengan menggunakan penilaian oleh pengguna, dapat disimpulkan bahwa sebagian besar dari responden menyatakan setuju bahwa sistem informasi geografis atau GIS pada penelitian kali ini bermanfaat dan dapat memudahkan pekerjaan para pekerja dalam memantau kondisi geografis suatu area. Selain itu, menurut pengguna, data dan informasi yang ditampilkan juga akurat. Namun, tidak di semua pernyataan pengguna merasa setuju ataupun sangat setuju. Pada pernyataan tertentu, terdapat pengguna yang menyatakan ragu-ragu. Yaitu, pada pernyataan 3 dan 4, 10\% pengguna menyatakan ragu bahwa GIS ini akan sangat membantu pekerjaan serta ragu bahwa GIS ini mudah untuk diakses kapanpun dan di manapun. Dari hasil analisis terhadap jawaban pengguna tersebut, maka diperoleh beberapa hal yang perlu dipertimbangkan. Hal pertama yang perlu dipertimbangkan adalah dibutuhkan penambahan sensor untuk membaca kondisi geografis perkebunan, tidak hanya sensor suhu, tekanan udara, kelembaban udara, dan curah hujan. Hal kedua yang perlu dipertimbangkan adalah dalam hal mengakses sistem informasi geografis berbasis website melalui gadget yang portable masih belum fleksibel, dapat dipertimbangkan untuk pembuatan aplikasi sistem informasi geografis yang berbasis Android.

\section{KESIMPULAN}

\subsection{Kesimpulan}

Berdasarkan hasil dari penelitian Rancang Bangun Geographic Information System (GIS) sebagai Pengembangan Sistem Monitoring Area Perkebunan Berbasis IoT, dapat disimpulkan beberapa hal sebagai berikut:

1. Sistem informasi geografis hadir sebagai salah satu solusi permasalahan sistem monitoring atau pemantauan kondisi geografis suatu area yang masih dilakukan secara konvensional.

2. Sistem informasi geografis berguna dalam kegiatan pemantauan kondisi geografis suatu area tanpa harus berada langsung di area yang dipantau, sehingga kegiatan-kegiatan operasional yang dilakukan dapat lebih efektif dan efisien.

3. Sistem informasi geografis ini menampilkan informasi kondisi geografis suatu area secara real-time.

4. Sistem informasi geografis ini dikembangkan dari sistem monitoring area perkebunan berbasis internet of things.

5. Informasi yang ditampilkan pada sistem informasi geografis ini menggunakan tampilan peta (map) dengan blok-blok area yang dipantau.

6. Data kondisi geografis yang ditampilkan oleh sistem informasi geografis ini adalah suhu (temperature), kelembaban udara (humidity), tekanan udara (pressure), dan curah hujan (rainfall).

7. Sistem informasi geografis ini berhasil menggambarkan kondisi geografis suatu area dengan beberapa ragam warna. Warna merah digunakan untuk menggambarkan kondisi geografis yang kritis. Warna kuning digunakan untuk menggambarkan kondisi geografis suatu area yang rawan kritis, di kondisi ini, pengguna dapat melakukan estimasi ataupun perkiraan tindakan untuk menghadapi kemungkinan berada pada 
kondisi kritis kedepannya. Warna hijau muda digunakan untuk menggambarkan kondisi geografis suatu area yang cukup baik (normal) dan warna hijau tua digunakan untuk menggambarkan kondisi geografis suatu area yang paling baik.

8. Berdasarkan hasil penilaian pengguna: $80 \%$ responden menyatakan sangat setuju dan $20 \%$ responden menyatakan setuju bahwa sistem ini bermanfaat bagi para pengguna dalam memantau kondisi geografis suatu area secara real-time. $60 \%$ responden menyatakan sangat setuju dan $40 \%$ responden menyatakan bahwa sistem bersifat user-friendly. 10\% responden ragu-ragu, 70\% menyatakan sangat setuju dan $20 \%$ responden setuju bahwa sistem ini akan sangat membantu pekerjaan. $50 \%$ responden memilih untuk sangat setuju, $40 \%$ responden memilih untuk setuju, dan 10\% responden ragu-ragu terhadap pernyataan bahwa sistem ini mudah untuk diakses kapanpun dan di manapun. 70\% responden menyatakan sangat setuju dan $30 \%$ responden menyatakan setuju bahwa sistem memiliki kecepatan akses yang baik. 40\% menyatakan sangat setuju dan $60 \%$ responden menyatakan setuju bahwa sistem dapat memberikan informasi yang akurat.

\section{UCAPAN TERIMAKASIH}

Ucapan terimakasih saya sampaikan kepada pihak-pihak yang telah mendukung terlaksananya penelitian ini, yaitu Bapak Iwan Pahendra Anto Saputra dan Bapak Zaenal Husin selaku rekan senior dan rekan satu tim penelitian bersama saya, Taqiyyah Nurul Fadhilah selaku mahasiswa yang membantu terlaksananya penelitian, para responden, serta para teknisi di laboratorium Teknik Telekomunikasi dan Informasi Program Studi Teknik Elektro Universitas Sriwijaya.

\section{REFERENCES}

[1] A. Aini, "Sistem Informasi Geografis: Pengertian dan Aplikasinya," Staff Pengajar STMIK AMIKOM, Yogyakarta.

[2] N. Patawaran dan F. X. Manggau, "Sistem Informasi Geografis Lahan Perkebunan Karet Di Kabupaten Merauke Berbasis Web," Musamus Journal Of Research Information and Communications Technology, vol. 1, no. 1, pp. 36-40, 2018.

[3] F. Akmal, F. Ramdani dan A. Pinandito, "Sistem Informasi Pengelolaan Perkebunan Kelapa Sawit Berbasis Web GIS," Jurnal Pengembangan Teknologi Informasi dan Ilmu Komputer, vol. 2, no. 5, pp. 1894-1901, 2018.

[4] M. Yanto, "Sistem Informasi Geografis Lokasi Perkebunan Disepanjang Garis Pantai Pesisir Selatan Berbasis Android," Jurnal Imiah Media Sisfo, vol. 13, no. 1, pp. 28-37, 2019.

[5] E. Irwansyah, Sistem Informasi Geografis: Prinsip Dasar dan Pengembangan Aplikasi, Yogyakarta: Digibooks Printing and Publishing, 2013.

[6] M. P. D. Zenaro, Artist, Introduction to the Internet of Things. [Art]. The Abdus Salam International Centre for Theoretical Physics Trieste.

[7] P. A. Grilo, "Internet of Things: An Introduction," [Online]. Available: https://fenix.Tecnico.Ulisboa.Pt/homepage/ist14017. [Diakses 13 Maret 2019].

[8] T. Point, Tutorials Point: Internet of Things, India: Tutorials Point (I) Pvt. Ltd, 2016.

[9] R. Society, “The Internet of Things: Opportunities and Threats,” Royal Society, 2017.

[10] M. A. Matin dan M. M. Islam, “Overview of Wireless Sensor Network,” Intech, 2012.

[11] A. Budiyanto, “alex.budiyanto@cloudindonesia.org,” Komunitas Cloud Computing Indonesia, 2012. [Online]. Available: www.cloudindonesia.org. [Diakses 20 Maret 2019].

[12] "Google Maps Platform," [Online]. Available: https://developers.google.com/maps/documentation. [Diakses 7 September 2020].

[13] A. Susanto, A. Kharis dan T. Khotimah, "Sistem Informasi Geografis Pemetaan Lahan Pertanian Dan Komoditi Hasil Panen Kabupaten Kudus,” Jurnal Informatika, vol. 10, no. No.2, pp. 1233-1243, 2016. 
[14] Mambang, "Sistem Informasi Geografis Pemetaan Hasil Perkebunan dan Pertanian," dalam Konferensi Nasional Sistem \& Informatika, Bali, 2017.

[15] K. M. Wibowo, I. Kanedi dan J. Jumadi, "Sistem Informasi Geografis (Sig) Menentukan Lokasi Pertambangan Batu Bara Di Provinsi Bengkulu Berbasis Website,” Jurnal Media Infotama, vol. 11, no. No.1, pp. 51-60, 2015.

[16] Kholil, "Pemanfaatan Sistem Informasi Geografis (Sig) Dalam Aplikasi Pelaporan Dan Pelacakan Kejahatan Berbasis Android," Jurnal Teknologi Informasi dan Komunikasi, vol. 6, no. No.1, pp. 51-58, 2017.

[17] N. Rahmawati, R. Saputra dan A. Sugiharto, "Sistem Informasi Geografis Pemetaan Dan Analisis Lahan Pertanian Di Kabupaten Pekalongan,” Journal of Informatics and Technology, vol. 2, no. No.1, pp. 95-101, 2013. 